\title{
A dialética de república e democracia no jovem Marx, entre Espinosa e Rousseau
}

\author{
Vittorio Morfino
}

Universidade de Milano-Biccoca 



\section{O lugar da Kritik}

A obra de Marx que aqui pretendo considerar foi escrita em 1843, sob a forma de uma série de anotações sobre a terceira seção (o Estado) da terceira parte (a Eticidade) dos Princípios da filosofia do direito de Hegel, em particular sobre os parágrafos 261-313, ou seja, a quase totalidade dos parágrafos dedicados por Hegel ao "Direito estatal interno" (do 260 ao 320). A obra, pelo menos sua última redação, foi escrita no período de Kreuznach, antes da mudança para Paris, entre a primavera e o verão de 1843, mas foi publicada apenas no século seguinte, em 1927, por Rjazanov. Pertence à tradição da glosa, na medida em que consiste na cópia do parágrafo hegeliano, seguido pelo comentário crítico marxiano.

Sem entrar aqui nos detalhes do debate filológico que apaixonou o século passado, basta recordar as grandes posições paradigmáticas com respeito à questão da obra de juventude de Marx: a posição continuísta, que vê nessas obras o germe filosófico da crítica subsequente à economia, e a posição descontinuísta, que introduz uma ruptura entre a obra de juventude e a obra madura. A essa segunda posição pertencem tanto a interpretação de Louis Althusser quanto a de Galvano Della Volpe, que se diferenciam ao situar essa ruptura em diferentes pontos temporais. Do ponto de vista de nosso tema, é interessante notar que, enquanto Althusser situa a Kritik em pleno período de juventude, com temas comandados por uma problemática feuerbachiana (Cf. Althusser, 1965), Della Volpe vê na Kritik a obra de ruptura de Marx com a consciência filosófica precedente ${ }^{1}$ (trata-se de uma interpretação de uma passagem de Marx da Introdução de 1959). Que a questão não é simplesmente filológica, mas toca o núcleo da tradição marxista, é o que se vê pelo fato de Negri, apresentando uma nova

1 “[...] é evidente como nasce aqui [na Kritik] a consciência daquele novo método dialético-materialístico enquanto dialético-experimental (galileano) que será aplicado à investigação (histórico-dialética) do Capital [...]” (Della Volpe, 1997, p. 143). 
edição da Kritik, publicada em 2008 pela Quodlibet com comentários críticos de Clio Pizzingrilli, escrever o seguinte:

Quem teria jamais pensado encontrar-se diante de um novo comentário tão original e criativo quanto este que Clio Pizzingrill apresenta da Crítica do direito de Hegel, quarenta anos depois de Louis Althusser ter liquidado essa obra, como 'humanista', indigna de estar ao lado das obras 'materialistas' que Marx redige depois do 'corte'? O que interessa não é a crítica de Althusser - o que interessa é o fato de que o novo comentário de Pizzingrilli soa original, exatamente no terreno do materialismo, e criativo, exatamente no âmbito das análises da força-trabalho que, mais do que qualquer outro, escandalizava Althusser em seu estudo do jovem Marx. O fato é que Pizzingrilli, relendo o Marx da Crítica do direito de Hegel, o faz a partir do novo nível que a luta operária, anticapitalista, produziu, no terreno do trabalho imaterial, cognitivo, 'alienado' (Negri, in Marx, 2008, p. 7).

Para retomar brevemente o argumento de Negri, digamos que ele admite que Althusser tinha razão ao considerar a categoria de alienação como idealista em uma fase histórica na qual as relações de produção não eram caracterizadas pelo trabalho cognitivo, mas que, na fase atual, a alienação seja a "expropriação direta do fazer do trabalho cognitivo, do saber operário, intelectual e linguístico" (Ibid., p. 8).

O movimento de pensamento negriano joga com a linha do tempo. A Kritik de Marx é falsa (idealista) com respeito ao seu tempo, mas verdadeira (materialista) com respeito ao futuro, isto é, o nosso tempo, o tempo do trabalho cognitivo.

Negri aplica o mesmo movimento ao conceito de 'comum' e ao conceito de 'ultrapassamento do Estado', que ele encontra na democracia absoluta teorizada pelo jovem Marx, "reproduzindo-a dentro da hipótese espinosista”, ideia falsa (idealista) e irrealizável no tempo de Marx, mas verdadeira (materialista) e praticável com respeito ao nosso tempo, o tempo do trabalho imaterial: 
Voltemos por isso a falar de democracia absoluta: é ao deslocar inteiramente a dinâmica da construção institucional de cima para baixo, do poder à potência $[\ldots]$ que a ideia de democracia se torna operativa - virando Hegel ao avesso, de verdade, e não de brincadeira. Não mais forma de governo, mas fonte de governo, não mais máquina de legitimação, mas construção direta dos valores: está aí a imanência absoluta do político-democrático. (Ibid., p. 9)

Alienação e democracia são, portanto, categorias proféticas do jovem Marx: idealistas com respeito a seu próprio tempo, tornam-se instrumentos de interpretação e transformação do futuro, do nosso tempo.

\section{O conceito de soberania}

Dirijamo-nos ao texto marxiano. De um ponto de vista metodológico, Marx enfrenta Hegel com duas armas críticas fundamentais: 1) a crítica feuerbachiana da inversão sujeito-predicado (nos meses de Kreuznach, Marx lê as Teses provisórias para uma reforma da filosofia), e 2) a crítica de Trendelemburg à interpolação sub-reptícia do empírico. Aplicando essas críticas à filosofia política hegeliana, Marx pensa, por um lado, que Hegel toma os sujeitos reais por predicados e os predicados por sujeitos (es. a inversão de família e sociedade civil que, de sujeitos, tornam-se predicados do Estado), e, por outro, que, elevando o empírico ao lógico, finge deduções onde, em realidade, há tão-somente uma descrição do existente.

Mas concentremo-nos agora na passagem em que Marx propõe aquilo que Negri chama de uma "democracia absoluta". Trata-se do comentário ao parágrafo 279 e à sua nota explicativa. No parágrafo 279, Hegel deduz o monarca da ideia de soberania:

A soberania, a princípio apenas o pensamento universal dessa idealidade, existe apenas como a subjetividade certa de si mesma e como a autodeterminação abstrata, e em tal medida privada de fundamento, da vontade 
em cuja autodeterminação reside o elemento último da decisão. É esse o individual do estado enquanto tal, estado que é uno. Mas a subjetividade é verdadeira apenas como sujeito, a personalidade somente como pessoa, e na constituição que alcance realidade racional tem sua encarnação real e separada para si cada um dos três momentos do conceito. Tal elemento decisivo, absoluto do conjunto, não é, então, a individualidade em geral, mas um indivíduo: o monarca. (Marx, 1982, pp. 23-24)

Para Marx é fácil iluminar a inversão sujeito-predicado operada por Hegel, que torna necessária a subsunção sub-reptícia do empírico, isto é, do monarca:

[A soberania] deveria ser obra consciente dos sujeitos, e como tal, existir por eles e neles. Se Hegel tivesse tomado, como ponto de partida, os sujeitos reais como base do Estado, não teria achado necessário subjetivar, de maneira mística, o Estado. A “subjetividade”, diz Hegel, “é em sua verdade somente como sujeito, a personalidade somente como pessoa". Também isso é uma mistificação. A subjetividade é uma determinação do sujeito, a personalidade uma determinação da pessoa. Ao contrário de concebê-los como predicados de seus sujeitos, Hegel torna os predicados independentes e deixa se transmutarem, de maneira mística, em seus sujeitos. (Ibid., p. 24)

Segundo Marx, Hegel deduz o monarca a partir da soberania precisamente porque parte da ideia de soberania, predicado dos sujeitos reais, e faz dela o sujeito: nesse ponto torna-se necessário dar um corpo à ideia, encarná-la em um sujeito real, e esse sujeito é o monarca. Nesta passagem mostra-se, segundo Marx, o andamento típico do pensamento hegeliano:

A existência dos predicados é o sujeito: portanto, sujeito é a existência da subjetividade etc. Hegel dá uma existência independente aos predicados, aos objetos, mas abstraindo-os de seu sujeito, que é realmente independente. Em seguida, o sujeito real aparece como resultado deles, 
quando, ao contrário, é preciso partir do sujeito real e considerar o seu objetivar-se. A mística substância torna-se, pois, o sujeito real, e o sujeito real aparece como alguma outra coisa, como um momento da mística substância. Precisamente na medida em que Hegel toma o movimento dos predicados da determinação geral, em vez do ente real (hypokeimenon, sujeito), e que deve haver todavia um suporte dessas determinações, a mística ideia se torna esse suporte. (Ibid., pp. 24-25)

Portanto, a inversão sujeito-predicado faz com que "a soberania, a essência do Estado [seja] considerada como uma essência independente, objetivada”, e com que, depois, deva "voltar a ser sujeito": "mas", conclui Marx, "esse sujeito aparece então como uma auto-reincarnação da soberania, ao passo em que a soberania não é nada, senão o espírito objetivado dos sujeitos do Estado" (Ibid.).

A essa inversão acrescenta-se ainda a interpolação sub-reptícia do empírico, precisamente para dar conteúdo real ao predicado elevado a sujeito. De onde vem o monarca? No parágrafo que já lemos, Hegel responde: “na constituição que alcance realidade racional tem sua encarnação real e separada para si cada um dos três momentos do conceito. Tal elemento decisivo, absoluto do conjunto, não é, então, a individualidade em geral, mas um indivíduo: o monarca”. Em outras palavras, o arcabouço lógico da constituição impõe uma articulação nos três momentos fundamentais do conceito: a universalidade, a particularidade e a individualidade. E, todavia, Hegel dá um salto, pois a individualidade não é o indivíduo. Em outras palavras, Marx acredita que, partindo do predicado, da soberania, e não do sujeito, Hegel seja forçado a subsumir um indivíduo para dar corpo ao predicado. Portanto, o empírico, o arbítrio, é interpolado no lógico, precisamente porque o lógico se põe como substantificação de predicados que, depois, devem encontrar um suporte empírico.

\section{A dialética defectiva de monarquia e democracia}

Nas linhas seguintes, Hegel enfrenta a questão da soberania 
popular: "Soberania popular", escreve, "pode ser dita no sentido de que um povo em geral seja independente em relação ao exterior e constitua um Estado" (Ibid., p. 29). Não transcrito por Marx, Hegel cita os exemplos históricos da "Inglaterra, ou Escócia, Irlanda, ou de Veneza, Gênova, Ceilão etc.”, que deixaram de ser povos soberanos no momento em que "deixaram de ter por si mesmos governos supremos ou príncipes". (Hegel, 2009, p. 234) Marx comenta que o raciocínio hegeliano é trivial:

Se o príncipe é a 'soberania real do Estado', ele deve também poder valer no exterior como o "Estado autônomo", mesmo sem o povo. Mas se ele é soberano enquanto representa a unidade do povo, ele é apenas o representante, o símbolo da soberania popular. A soberania do povo não é por meio dele, é ele, ao contrário, que é, através da soberania popular. (Marx, 1982, p. 29)

Se o monarca encarna a soberania, isso deveria valer seja com relação ao interior, seja com relação ao exterior. Em realidade, Hegel concede que, com relação ao exterior, há soberania popular no sentido de um povo independente. Para Marx não é difícil mostrar que o monarca é o mero representante dessa soberania e não a sua encarnação. Ainda uma vez, é a inversão sujeito-predicado, desmascarada por Feuerbach, que está no coração do pensamento hegeliano: separando o predicado (a soberania) do sujeito (o povo), Hegel é obrigado a subsumir o empírico, o monarca, para dar um substrato real ao predicado abstrato.

Quanto à soberania em relação ao interior, continua Hegel, “pode-se também dizer que ela resida no povo, se se fala apenas em geral do interior, assim como antes $\left(\mathbb{\int} \int 277,278\right)$ foi mostrado que a soberania respeita o Estado" (Ibid.). Marx fica furioso: "Como se o povo não fosse o Estado real! O Estado é um abstrato. Apenas o povo é o concreto. E é notável que Hegel, que o faz sem hesitar para o abstrato, atribua apenas com hesitações e reservas uma qualidade viva como a soberania" (Ibid.). 
É precisamente porque Hegel deu uma vida autônoma ao predicado, à soberania, que ele tem dificuldade em reconhecer o sujeito desse predicado. O Estado não é senão uma abstração, quando separado do povo, mas é autonomizando esse predicado que Hegel termina por lhe dar o monarca como corpo empírico. Por isso, Hegel toma definitivamente distância de uma concepção da soberania popular concebida em antítese com a soberania do monarca:

A soberania popular, enquanto tomada em oposição à soberania existente no monarca, é o sentido ordinário em que recentemente se começou a falar de soberania popular - nessa oposição, a soberania popular pertence aos pensamentos confusos, nos quais se funda a representação vulgar do povo (Ibid.).

\section{Marx replica:}

As "ideias confusas" e "a representação incauta" encontram-se apenas em Hegel. Sem dúvida, se a soberania existe no monarca, é uma tolice falar em soberania contrária existente no povo, pois é próprio do conceito de soberania que essa não possa ter uma dupla e diretamente oposta existência. Mas, 1) a questão é precisamente: não é uma ilusão a soberania que se absorve no monarca? Soberania ou do monarca ou do povo, eis a question ; 2) pode-se também falar de uma soberania popular, em antítese à soberania existente no monarca. Mas então não se trata de uma única e mesma soberania derivada das duas partes, mas sim de duas noções inteiramente opostas de soberania, da qual uma é tal que se pode realizar apenas num monarca, e a outra é tal que só se pode realizar no povo; como ocorre igualmente quando se pergunta se é Deus o soberano ou se é o homem o soberano. Uma das duas é uma falsidade, ainda que uma falsidade existente. (Ibid., pp. 29-30)

A Hegel, que repete o célebre aforisma hobbesiano segundo o qual rex est populus e que, portanto, pode falar de soberania 
popular na medida em que essa se encarna na figura do rei, Marx replica que a soberania que se encarna no rei é uma falsidade, embora existente, porque exibe o caráter popular enquanto predicado tornado autônomo com respeito ao sujeito legítimo, o povo. Hegel reforça a ascendência hobbesiana de seu argumento:

Sem seu monarca, e sem a articulação que imediatamente e necessariamente dele provém, o povo é uma massa informe, deixa de ser um Estado e não possui nenhuma das determinações que existem no todo organizado: soberania, governo, justiça, autoridade, os estados [Stände] etc. Tão logo num povo surjam esses elementos associados à vida e à organização política, deixa ele de ser uma abstração indeterminada, como acontece na concepção geral de povo (Ibid., p. 30)².

O povo sem monarca não tem articulação orgânica e, portanto, uma tal abstração indeterminada não pode ser o sujeito da soberania. Marx considera que esse discurso é sofístico, pois parece pressupor que a única organização possível é a monárquica:

É tudo uma tautologia. Se um povo tem um monarca e uma organização necessária e imediatamente conexa, isto é, se ele é organizado numa monarquia, ele é certamente, uma vez fora dessa estrutura, uma massa informe e uma representação meramente geral (Ibid.).

Todavia, nas linhas seguintes da nota, Hegel enfrenta a questão de uma organização diferente do povo: "Se, por soberania popular, entende-se a forma da república, e, mais determinadamente, da democracia, (...) então (...), frente à ideia desenvolvida, não se pode mais falar numa tal representação" (Ibid.). Essa é a frase transcrita por Marx. No texto hegeliano, encontramos um parêntese, não sem interesse, que segue imediatamente o termo 
'democracia': “por república entende-se todo tipo de múltiplas misturas empíricas, que em todo caso não têm que ver com uma consideração filosófica” (Hegel, 2009, p. 234). A réplica de Marx é irônica: ele afirma que Hegel tem sem dúvida razão "se se tem da democracia apenas uma 'semelhante concepção' e nenhuma “ideia desenvolvida”' (Marx, 1982, p. 30). Noutras palavras, Hegel não toma sequer em consideração a possibilidade de que a soberania se encarne no povo, dando vida a uma forma de Estado democrático, precisamente porque não tem qualquer ideia de Estado democrático.

E aqui a longa passagem na qual Marx apresenta sua própria concepção frente a Hegel, através de um estilo rico de quiasmas e de calembours típicos da esquerda hegeliana:

A democracia é a verdade da monarquia, a monarquia não é a verdade da democracia. A monarquia é necessariamente democracia como inconsequência em relação a si mesma, o elemento monárquico não é uma inconsequência da democracia. Contrariamente à monarquia, a democracia pode ser concebida através de si mesma. Na democracia, nenhum de seus elementos adquire um significado diverso daquele que lhe respeita. Cada um é realmente apenas um momento do demos inteiro. $\mathrm{Na}$ monarquia, uma parte determina o caráter do todo: a constituição inteira deve se modificar conforme um ponto fixo. A democracia é o genus da constituição [Verfassungsgattung]. A monarquia é uma espécie dela, e uma espécie perversa. A democracia é conteúdo e forma. A monarquia deve ser apenas forma, mas essa altera o conteúdo. Na monarquia, o todo, o povo é subsumido sob um dos seus modos de existir, a constituição política; na democracia, a constituição mesma aparece simplesmente como uma determinação, isto é, autodeterminação do povo. Na monarquia temos o povo da constituição; e na democracia, a constituição do povo. A democracia é o enigma resolvido de todas as constituições. Aqui, a constituição, não apenas in se, segundo a essência, mas segundo a existência, segundo a realidade, é reconduzida continuamente a seu fundamento real, ao homem real, ao povo real, e posta como obra própria dele. A cons- 
tituição aparece como o que é produto livre do homem. Poder-se-ia dizer que isso vale também, sob certo aspecto, para a monarquia constitucional: mas a diferença específica da democracia é que a constituição em geral é apenas um elemento de existência do povo, e não que a constituição política por si mesma forme o Estado. (Ibid., pp. 30-31)

A ascendência feuerbachiana da passagem não poderia ser mais evidente: a democracia, como a entende Marx, é o homem tomado como Gattungswesen, e enquanto tal, obviamente, como zoon politikon que se reapropriou da política alienada. Nesse sentido, a dialética de democracia e monarquia é uma dialética manca, unilateral: a democracia é a verdade da monarquia, mas não vice-versa; a monarquia é uma inconsequência da democracia, mas não vice-versa; a democracia pode ser concebida por si mesma, a monarquia não (ela deve ser concebida através da democracia); na democracia cada elemento é um momento do povo, enquanto na monarquia um elemento se destaca dele.

Essa dialética defectiva é fundada numa proposição capital: a democracia é Gattungsverfassung. A democracia é a essência desvelada do homem político, "o enigma resolvido de todas as constituições”, enquanto a monarquia não é senão uma forma alienada dele: por isso a primeira é forma e conteúdo, enquanto a segunda, forma que altera o conteúdo; a primeira é essência e existência, enquanto a segunda é essência alienada, essência que não se manifesta senão numa distorção mesmo na forma da monarquia constitucional, pois, na monarquia, o povo aparece apenas na forma transfigurada da legalidade constitucional, isto é, depois da instauração do poder, identificando-se com o rei, enquanto na democracia a constituição é uma determinação do povo, uma autodeterminação, um produto livre do homem.

A ascendência feuerbachiana revela-se com clareza na passagem seguinte:

Hegel parte do Estado e faz do homem o Estado subjetivado; a democra- 
cia parte do homem e faz do homem o Estado objetivado. Assim como não é a religião que cria o homem, mas o homem que cria a religião, tampouco a constituição é que cria o povo, pois é o povo que cria a constituição. A democracia está, sob certo ponto de vista, para todas as outras formas políticas, como o cristianismo está para todas as outras religiões: o cristianismo é a religião kat'exochen, a essência da religião, o homem deificado numa religião particular. Assim, a democracia é a essência de toda constituição política, o homem socializado numa constituição política particular, e esta está para as outras constituições assim como o gênero está para suas espécies. Com a diferença que nela o gênero mesmo se manifesta como existência, e, contudo, como uma espécie particular frente às existências não correspondentes à essência. A democracia está para todas as outras formas políticas como para seu Antigo Testamento. O homem não existe pela lei, mas a lei existe pelo homem, é existência humana, enquanto nas outras formas o homem é existência legal. Essa é a diferença fundamental da democracia. (Ibid., p. 31)

Portanto, Marx o diz explicitamente, o esquema feuerbachiano de interpretação da religião é aplicado à política: Deus não é sujeito, mas predicado do homem, assim como a constituição não é sujeito, mas predicado do povo.

Em um escrito publicado póstumo dedicado a Feuerbach, Althusser exibiu com precisão os mecanismos da problemática feuerbachiana: a teoria da religião como objeto próprio, objeto essencial, do homem enquanto exteriorização, objetivação da sua essência que Feuerbach expõe na Essência del Cristianismo, insistindo várias vezes sobre a especularidade dos predicados de Deus e dos predicados do homem. Todavia, esse objeto, objeto absoluto do homem, exprime a essência genérica do homem na forma da opacidade, ou seja, "na religião e em todos os seus atos genéricos, o homem se relaciona com a consciência de si; mas, sem a consciência, isto é, sem a transparência” (Althusser, 1995, p. 197); essa opacidade é efeito da alienação e portanto "a consciência pode tornar-se adequada à consciência de si (vale dizer: a consciência de 
si pode tornar-se transparente) somente através a desalienação do homem, através do inversão do sentido e a restauração do sentido original, autêntico, através do desvelamento" (Ibid.).

No interior dessa problemática funciona o discurso marxiano: há uma simples substituição de objeto essencial, a política pela religião. A democracia é a essência mesma da política, assim como a religião cristã é a essência mesma da religião, precisamente porque em ambas se exprime o sujeito enquanto tal: o homem, o povo no âmbito do político, o homem-deus no âmbito religioso. E assim como o homem-Deus é gênero, enquanto essência de todos os homens, mas também existência, a democracia é gênero, enquanto essência de toda forma constitucional, mas também existência real, espécie, entre as outras espécies constitucionais. Como esclarece Marx,

Todas as outras formações políticas são uma certa, determinada, e particular forma de Estado. Na democracia, o princípio formal é ao mesmo tempo o princípio material. Essa é portanto a verdadeira unidade do universal e do particular. Na monarquia, por exemplo, ou na república como forma simplesmente particular de Estado, o homem político tem sua existência peculiar ao lado do homem não-político, do homem privado. A propriedade, o contrato, o matrimônio, a sociedade civil aparecem aqui (segundo a exatíssima explicação hegeliana dessas formas políticas abstratas, salvo que Hegel acredita explicar a ideia de Estado) como modos de existência particulares ao lado do Estado político, como o conteúdo, em cujos confrontos o Estado político se comporta como a forma organizadora, e propriamente como o intelecto sem conteúdo em si mesmo, determinante e limitante, que ora afirma, ora nega. Na democracia, o Estado político, enquanto se põe ao lado desse conteúdo e dele se distingue, é ele mesmo apenas um conteúdo particular, como um modo de existir particular do povo. Na monarquia, por exemplo, a constituição política, esse particular, tem o significado do universal, que domina e determina todo o particular. Na democracia, o Estado, enquanto particular, é apenas particular, e enquanto universal é o universal real, isto é, nada 
de determinado que seja distinto do outro conteúdo. Os franceses modernos entenderam isso do seguinte modo: que na verdadeira democracia $o$ Estado político perece. Isso é certo, no sentido de que ele, como Estado político, como constituição, não vale mais pelo todo. Em todos os Estados que diferem da democracia, o Estado, a lei, a constituição dominam sem dominar realmente, isto é, sem penetrar materialmente no conteúdo das demais esferas não políticas. Na democracia, a constituição, a lei, o Estado mesmo, são simplesmente uma autodeterminação do povo, um conteúdo determinado do povo. (Marx, 1982, pp. 31-32)

\section{A dialética abstrata de monarquia e república}

Nesse ponto, Marx retorna sobre seus passos e mostra como a mesma dialética de monarquia e república é, na realidade, uma dialética abstrata, em que abstrair significa, segundo a definição feuerbachiana, "pôr a essência da natureza fora da natureza, a essência do homem fora do homem, a essência do pensamento fora do ato do pensamento" (Feuerbach, 1970, p. 247), portanto, prolongando a lógica do discurso feuerbachiano, a essência da sociedade fora da sociedade. A verdade dessa oposição, que se passe inteiramente no plano do Estado abstrato, é a democracia:

De resto, compreende-se por si mesmo que todas as formas políticas têm como sua verdade a democracia, e que, por isso, enquanto não são democracia, não são verdadeiras. Nos Estados antigos, o Estado político constitui o conteúdo do Estado com a exclusão das outras esferas; o Estado moderno é um compromisso entre o Estado político e aquele não político. Na democracia, o Estado abstrato deixou de ser o momento dominante. O conflito entre monarquia e república é ele mesmo um conflito no interior do Estado abstrato. A república política é a democracia no interior da forma política abstrata. A forma política abstrata da democracia é, pois, a república: mas aqui ela deixa de ser a constituição simplesmente política. A propriedade etc., em suma, todo o conteúdo do direito e do Estado é, com poucas modificações, o mesmo na América do Norte e na Prússia. Lá, a república é, pois, uma simples forma política, 
como aqui o é a monarquia: o conteúdo do Estado encontra-se fora dessas constituições. (...) A vida política no sentido moderno é a escolástica da vida do povo. A monarquia é a expressão realizada dessa alienação. A república é a negação de si mesma dentro de sua própria esfera. Entende-se que a constituição política como tal é desenvolvida apenas ali onde as esferas privadas adquiriram uma existência independente. Ali onde o comércio e a propriedade fundiária não são livres, ainda não se tornaram independentes, não o é tampouco a constituição política. A Idade Média era a democracia da não-liberdade. A abstração do Estado como tal pertence somente ao tempo moderno, porque a abstração da vida privada pertence apenas ao tempo moderno. A abstração do Estado político é um produto moderno. (Ibid., pp. 32-33)

Aparece aqui, finalmente, o termo alienação, amplamente anunciado pela problemática feuerbachiana das páginas precedentes: o Estado, a política, revela ser uma forma alienada enquanto tal. A monarquia encarna essa forma de alienação por excelência, é sua "forma realizada" e, todavia, a república não é a reapropriação da essência do povo, mas a negação dessa alienação, na forma ainda alienada da política, uma negação abstrata, exatamente como em Feuerbach "o panteísmo é a negação da teologia, realizada do ponto de vista da teologia”, ao passo que só na "viravolta $[\mathrm{da}]$ filosofia especulativa $[. .$.$] teremos finalmente a$ verdade nua, a pura, a genuína verdade”: "o ateísmo é o panteísmo às avessas” (Ibid., p. 245). A república está para o panteísmo como a democracia está para o ateísmo. A democracia é a verdadeira reapropriação da essência alienada, que é ao mesmo tempo negação do dualismo público/privado, gerado pela alienação estatal. E aqui o sujeito, identificado anteriormente por Marx no povo, toma uma forma diversa: o sujeito é a sociedade e a democracia não é senão o reapropriar-se das forças alienadas dessa sociedade.

\section{Os excertos do Contrato social}

Examinamos até aqui os argumentos marxianos em que a de- 
mocracia é oposta à monarquia e à república. Se, como vimos, a problemática que estrutura o discurso marxiano é sem sombra de dúvida feuerbachiana, trata-se de compreender se uma outra genealogia pode ser traçada, uma genealogia mais propriamente política, uma genealogia das posições democráticas no interior da modernidade. Nesse sentido, é inevitável referir-se a Espinosa e a Rousseau 3 . Contudo, tentaremos reconstruir essa genealogia não em termos abstratos, como uma espécie de retrato de família, e sim de um ponto de vista histórico-filológico. Existem, de fato, excertos marxianos tanto do Contrato social quanto do Tratado teológico-político.

Os extratos de Contrato social pertencem ao intenso período de estudo de Kreuznach e portanto são contemporâneos à Kritik. Testemunha do estudo desse período são seis cadernos de notas, entre os quais para nós tem particular interesse o segundo, intitulado editorialmente pelos MEGA "Notizen zur Geschichte Frankreichs, Venedigs und Polens und Exzerpte aus staatstheoretischen Werken”, datados, sempre editorialmente, “juli august 1843”. O cadernos contêm uma série de notas, extraídas de obras sobre a história francesa, polonesa e da república veneziana, e extratos do Contrato social e do Esprit des lois, de Montesquieu.

Repassemos rapidamente o conteúdo desses extratos, no que eles se referem à obra de Rousseau. Do primeiro livro do Contrato social Marx copia passagens de todos os capítulos. Do primeiros cinco capítulos polêmicos contra aqueles que Rousseau chama

3 Sobre a relação Marx-Espinosa, cf. Chaui, 1983; Y. Yovel, "Marx's Ontology and Spinoza's Philosophy of Immanence", Studia spinozana, 9, 1993, pp. 217-227; H. Seidel, "Spinoza und Marx über Entfremdung - ein komparatistischer Versuch", Studia spinozana, 9, 1993, pp. 229-243; M. Rubel, "Marx à la rencontre de Spinoza”, Cahiers Spinoza, 1, 1977, pp. 7-28; A. Igoin, "De l'ellipse de la théorie politique de Spinoza chez le jeune Marx", Cahiers Spinoza, 1, 1977, pp. 213-216-228 ; M. Rubel, "Marx à l'école de Spinoza. Contribution à l'étiologie de l'aliénation politique”. In: E. Giacontti (ed.), Spinoza nel 350 della nascita, Napoli, Bibliopolis, 1984, pp. 381-399. Sobre Marx e Rousseau cf. o clássico G. della Volpe, Rousseau e Marx, Roma: Editori Riuniti, 1957. Su Marx, Spinoza e Rousseau cf. E. Balibar, "Le Politique, la Politique. De Rousseau à Marx, de Marx à Spinoza”, Studia spinozana, 9, 1993, pp. 203-215. 
"os fautores do despotismo", Marx copia apenas poucas linhas, em que está posta a antítese entre o estado de natureza em que o homem é livre e a sociedade em que ele é escravo. O capítulo seis é apresentado em seus pontos cruciais: trata-se de "encontrar uma forma de associação que defenda e proteja com toda a força comum a pessoa e os bens de cada associado, e para o qual cada um, unindo-se a todos, não obedeça todavia senão a si mesmo, e reste livre como antes” (Marx, 1981, p. 91). Única cláusula é “a alienação total de cada associado com todos os seus direitos a toda a comunidade" (Ibid.). Excluindo o não essencial, Marx copia os termos em que Rousseau formula o pacto social: "Cada um de nós põe em comum a sua pessoa e todo seu poder sob a suprema direção da vontade geral; e recebemos enquanto corpo cada membro como parte indivisível do todo". E continua o extrato:

Em lugar da pessoa isolada de cada contratante, esse ato de associação produz de imediato um corpo moral e coletivo composto de tantos membros quantos são os votos da assembleia; por esse mesmo ato, tal corpo moral recebe sua unidade, seu eu comum, sua vida e sua vontade. Essa pessoa pública, que [se forma assim] pela união de todas as outras, tomou uma vez o nome de cidade, [e agora o de] república o [de] corpo político, o qual por sua vez é chamado pelos seus membros Estado quando é passivo, soberano quando é ativo, potência com relação aos seus semelhantes. Os associados, pois, tomam coletivamente o nome de povo, e singularmente se chamam cidadãos na medida em que participantes da autoridade soberana, e submetidos na medida em que sujeitos à lei dos Estado. (Ibid., 92)

Dos últimos três capítulos Marx copia poucas linhas: em destaque, as passagens em que Rousseau identifica a liberdade com a obediência à vontade geral (o célebre "se o constrangerá a ser livre" [Ibid.]) e aqueles em que diferencia liberdade natural e liberdade civil, direito do primeiro ocupante e direito de propriedade. Marx detém-se, no entanto, na conclusão do primeiro Livro: 
Em vez de destruir a igualdade natural, o pacto fundamental ao contrário substitui uma igualdade moral e legítima àquele tanto de desigualdade física que a natureza pudera introduzir entre os homens; estes, embora podendo ser desiguais por força ou por engenho, tornam-se todos iguais por convenção e segundo o direito. (Ibid., p. 93)

E, acrescenta Marx, antes de copiar a nota, que "Rousseau macht zu dem letzen Satz folgende merkwürdige Note" (Ibid.):

Sob os maus governos essa desigualdade não é que aparente e ilusória; só serve para manter o pobre na sua miséria, e o rico na sua usurpação. De fato, as leis são sempre úteis àqueles que possuem, e danosas para aqueles que não têm nada; disso deriva que o estado social é vantajoso aos homens só na medida em que eles tenham todos algo e ninguém tenha demais. (Ibid., p. 94)

Do segundo livro Marx extrai passagens da quase totalidade dos capítulos (constituem exceção o capítulo cinco e o capítulo dez). O problema fundamental do livro é o da definição da vontade geral. Através dos extratos, Marx busca aprofundar o conceito: "A vontade geral pode dirigir as forças do Estado de modo conforme ao fim da sua instituição, que é o bem comum” (Ibid.). A soberania, que é o exercício da vontade geral, não é portanto alienável: "o soberano, ente coletivo [être collective], não pode ser representado senão por si mesmo: pode-se transmitir o poder, mas não a vontade” (Ibid.).

Ademais, "pela mesma razão por que é inalienável, a soberania é indivisível" (Ibid.). A esse propósito Marx copia a seguinte passagem de Rousseau:

Os nossos escritores políticos, não podendo dividir a soberania no seu princípio, a dividem no seu objeto [...] a dividem em força e vontade, em poder legislativo e poder executivo [...] Eles 
fazem do soberano um ente fantástico e formado de elementos justapostos [...] Esse erro deriva... de terem tomado por partes dessa autoridade aquelas que pelo contrário são suas emanações (Ibid.).

Quanto à questão se a vontade geral pode errar, Marx copia a seguinte passagem:

A vontade geral é sempre reta e tende sempre à utilidade pública: Não deriva disso, porém, que as deliberações do povo sejam sempre igualmente corretas. Quer-se sempre o próprio bem, mas nem sempre se o vê $[\ldots]$. Há amiúde muita diferença entre a vontade de todos e a vontade geral; esta almeja somente ao interesse comum, a outra ao interesse privado, e não é senão uma soma de vontades particulares. Mas, tolheis dessas vontades o mais e o menos, que se destroem mutuamente, resta como soma das diferenças a vontade geral [...] Quando se criam associações parciais às custas da grande, a vontade de cada associação torna-se geral com relação aos seus membros, e particular com relação ao Estado: pode-se então dizer que não há mais tantos votantes quantos são os homens, mas só tantas quantas são as associações (Ibid.).

Quanto aos limites do poder soberano, Marx copia em primeiro lugar a premissa rousseauniana:

Se o Estado ou a cidade não é senão uma pessoa moral cuja vida consiste na união dos seus membros, e se a mais importante das suas preocupações é a da própria conservação, é necessário que tenha uma força universal e coativa para mover e dispor cada parte da maneira mais conveniente ao todo. Como a natureza dá a cada homem um poder absoluto sobre todos os seus membros, o pacto social dá ao corpo político um poder absoluto sobre todos aqueles que estão como os seus membros; e é esse poder que, dirigido pela vontade geral, porta como disse o nome soberania (Ibid.).

E, em segundo lugar, a limitação fundamental proposta por Rousseau: 
A vontade geral, para ser verdadeiramente tal, deve sê-lo seja em seu objeto quanto em sua essência; que ela deve partir de todos para aplicar-se a todos; e que ela perde a sua retidão natural quando tende a algum objeto individual e determinado, porque então, julgando sobre isso que nos é estranho, não temos nenhum princípio de equidade que nos guie. [...] $\mathrm{O}$ poder soberano, por absoluto, sacro e inviolável que seja, não passa e não pode passar dos limites das convenções gerais, e todo homem pode dispor plenamente disso que dos seus bens e da sua liberdade lhe foi outorgado por essas convenções (Ibid., p. 97).

Marx passa então a copiar as passagens em que Rousseau define o ato pelo qual o povo delibera sobre todo o povo:

Não pode haver vontade geral sobre um objeto particular [...] quando o povo delibera sobre todo o povo não considera senão a si mesmo; e se nesse caso uma relação se forma, essa é entre o objeto inteiro, considerado de um certo ponto de vista, e o mesmo objeto inteiro, considerado de um outro ponto de vista, sem nenhuma divisão do todo. Então a matéria sobre a qual se delibera é geral como a vontade que delibera. É esse ato que eu chamo lei. Quando digo que o objeto das leis é sempre geral, pretendo dizer que a lei considera os súditos como corpo coletivo e as ações como abstratas, mas um homem como indivíduo é uma ação particular. Assim a lei poderá estabelecer que haja privilegiados, mas não pode dar privilégio nominativamente a ninguém: a lei pode constituir diversas classes de cidadãos, estabelecer também os requisitos que darão direito a essas classes, mas não pode nomear esses ou aqueles para serem aí admitidos; ela pode estabelecer um governo régio e uma sucessão hereditária, mas não pode eleger um rei, nem nomear uma família real: numa palavra, toda função que se refira a um objeto individual não pertence ao poder legislativo (Ibid., pp. 95-96).

Marx copia em seguida a definição rousseauísta de república: “[Chamo portanto] de república todo Estado regido por leis, qual- 
quer que seja a sua forma de administração". E acrescenta que "in der Anmerkung zu diesem Satze heisst es" (Ibid.), que para ser legítimo não é preciso que o governo se confunda com o corpo soberano, mas que seja o seu ministro: então a própria monarquia é república (Ibid.).

Marx transcreve a passagem em que é posta a necessidade de um legislador: "Por si o povo quer sempre o bem, mas por si nem sempre o vê. A vontade geral é sempre reta, mas o juízo que a guia nem sempre é iluminado" (Ibid.). E eis como Rousseau lhe define a tarefa, em outro extrato marxiano:

Aquele que ousa tomar a iniciativa de fundar uma nação deve sentir-se capaz de mudar, por assim dizer, a natureza humana, de transformar cada indivíduo, que por si mesmo é um todo perfeito e isolado, em parte de um todo maior, do qual esse indivíduo recebe de algum modo a vida e o ser, de alterar a constituição do homem para reforçála; de substituir uma existência parcial e moral pela existência física e independente que nós todos recebemos da natureza. É necessário ... que ele tire do homem as forças que the são próprias para dar-lhe outras que provenha de fora dele e que não possa usar sem a ajuda de outros. Quanto mais aquelas adquiridas forem maiores e duráveis, tanto mais a instituição mesma é sólida e perfeita: de modo que se cada cidadão não é nada, nem pode nada senão por meio de todos os outros, e se a força adquirida a partir do todo é igual ou superior a soma das forças naturais de todos os indivíduos, pode-se dizer que a legislação alcançou o mais alto grau de perfeição a que se pode chegar (Ibid.).

Nos breves extratos seguintes, Marx copia os argumentos rousseauístas sobre a excepcionalidade da figura do legislador, que deve dar leis a um povo permanecendo externo e acima da constituição da república, porque "quem comanda sobre as leis não deve comandar sobre os homens" (Ibid.): "Quando Licurgo deu leis à sua pátria, começou por abdicar ao poder régio. Era costume da maior parte das cidades gregas confiar a estrangeiros a instituição de suas leis" (Ibid., pp. 96-97). 
Depois de uma série de extratos de menor interesse a partir dos 3 capítulos dedicados por Rousseau ao povo, Marx copia dois trechos de grande importância do capítulo 11 sobre os "Diversos sistemas de legislação":

Deux objets principaux (sc. De tout système de législation) la liberté et l'égalité. La liberté, parce que toute dépendance particulière est autant de force ôtée au corps de l'état; l'égalité, parce que la liberté ne peut subsister sans elle.

C'est précisément parce que la force des choses tend toujours à détruire l'égalité, que la force de la législation doit toujours tendre a maintenir (Ibid., p. 97).

Finalmente Marx conclui os extratos do segundo livro introduzindo-os com estas palavras: "Rousseau kömmt nun am Schluss des $2^{\text {ten }}$ Buchs auf die division de loix". Eis a síntese que nos propõe acerca do que deve ser feito para dar a melhor forma possível à coisa pública:

[1] A ação do corpo inteiro que age sobre si mesmo, isto é, a relação do todo com o todo, ou do soberano com o Estado; e essa relação é composta por aqueles termos médios, como veremos adiante. As leis que regulam essa relação tomam o nome de leis politicas, e se chamam também leis fundamentais. [...]

[2] relação [...] dos membros entre si, ou com o corpo inteiro; e essa relação deve ser no primeiro caso o menor possível, e no segundo o maior possível; de modo que cada cidadão esteja numa perfeita independência relativamente a todos os outros, e numa extrema dependência relativamente a todos os outros, e numa extrema dependência relativamente à cidade [...] dessa relação ... nascem as leis civis.

[3] relação entre o homem e a lei, isto é, aquela de desobediência à pena; e isso dá lugar à instituição das leis criminais, que, no fundo, são não tanto uma categoria especial de leis quanto a sanção de todas as outras.

[4] [...] costumes, os usos, a opinião. (Ibid., p. 98) 
Do terceiro livro Marx tira uma série de extratos a partir de 7 entre 18 capítulos. Em primeiro lugar a partir do capítulo sobre o governo, os trechos em que Rousseau explica a sua função no Estado: “[...] o poder executivo [...] não pode pertencer à generalidade como legisladora o soberana, porque esse poder não consiste que em atos particulares que não são de competência da lei, nem por consequência de competência do corpo soberano" (Ibid.). O governo, continua o extrato marxiano, é portanto "um corpo intermediário instituído entre súditos e o corpo soberano pela recíproca correspondência entre eles, encarregado da execução das leis e da manutenção da liberdade seja civil, seja política” (Ibid., p. 81). A relação que liga o governo ao povo não é um contrato, como queria Pufendorf, mas um mandato: "o Estado existe por si mesmo ao passo que o governo existe só pelo Estado” (Ibid., p. 99).

Do segundo capítulo recolhe as passagens em que Rousseau explica que quanto mais os magistrados são numerosos, mais o governo é fraco:

Se todo o governo está nas mãos de um só homem, a vontade particular e a vontade de corpo estão perfeitamente reunidas, e por conseguinte esta última atinge o mais alto grau de intensidade possível. [...] o mais ativo dos governos é aquele de um só. Ist dagegen Gouvernement und legislative Gewalt vereint. ... unamos o governo à autoridade legislativa; façamos do corpo soberano o príncipe, e de todos os cidadãos outros tantos magistrados: então a vontade de corpo, confundida com a vontade geral, não terá maior atividade que ela, e deixará a vontade particular toda a sua força [...] estará no seu mínimo de força relativa ou atividade (Ibid.).

Todavia Rousseau precisa, no sucessivo extrato marxiano, que se refere à força relativa do governo e não à sua retidão: "porque, do contrário, quanto mais numerosos são os magistrados, tanto mais a vontade de corpo se aproxima da vontade geral; ao passo que, sob um magistrado único, essa mesma vontade de corpo não 
é [...] senão uma vontade particular" (Ibid., pp. 99-100).

Do capítulo sobre a divisão dos governos, Marx apresenta uma síntese do esquema proposto por Rousseau:

Distinguem-se as diversas espécies ou formas de governos por meio do número dos membros que o compõem: mais cidadãos magistrados do que simples cidadãos, democracia; o governo nas mãos de uma minoria, aristocracia; o governo nas mãos de um magistrado único do qual todos os outros recebem o poder deles, monarquia (Ibid.).

Do capítulo sobre democracia, Marx copia o trecho rousseauísta em que se sublinha a razão da sua insuficiência: "o príncipe e o soberano, sendo a mesma pessoa, formam, por assim dizer, apenas um governo sem governo. [...] Als Haupthinderniss der Demokratie führt Rousseau an dass das Volk von vedute generali auf oggetti particolari gewandt durch die Influenz der interessi privati negli affari pubblici, sich in der Eigenschaft als Gesetzgeber corrumpirt" (Ibid.).

Duas passagens de particular interesse sobre o governo democrático, no entanto, são interrompidas. Não será inútil retomá-las:

Tomando o termo - escreve Rousseau - em sua rigorosa acepção, nunca existiu uma verdadeira democracia, nem nunca existirá. É contra a ordem natural que a maioria governa e a minoria é governada. (Rousseau, 2001, p. 201)

Se houvesse um povo de deuses, ele se governaria democraticamente. Um governo tão perfeito não convém aos homens. (Ibid., p. 203)

Marx não copia nenhum trecho a propósito da aristocracia e uma breve passagem sobre a monarquia em que Rousseau sublinha que nela “a unidade moral do príncipe é ao mesmo tempo uma unidade física, na qual todas as faculdades que a lei reúne 
na outra com tatos esforço aqui se encontram naturalmente reunidas" (Marx, 1981, p. 98). Marx não copia passagens sobre qualidades e defeitos da monarquia.

Finalmente encontramos uma breve citação do capítulo 8 (“É o supérfluo dos privados que produz o necessário da coletividade. Disso deriva que o Estado civil não pode subsistir senão enquanto o trabalho dos homens dá mais do que as suas necessidades" [Ibid.]) e amplas citações do capítulo 15 dedicado aos deputados e representantes, das quais a seguinte é sem dúvida fundamental:

A tibieza do amor de pátria, a atividade do interesse privado, a imensa extensão dos Estados [as conquistas], o abuso do governo, levaram a excogitar o expediente dos deputados o representantes do povo nas assembleias da nação. É isso que em certos países se ouse chamar o terceiro estado. Assim o interesse particular de duas ordens é colocado em primeiro e em segundo lugar; o interesse público vem somente em terceiro. A soberania não pode ser representada, pela mesma razão por que não pode ser alienada; ela consiste essencialmente na vontade geral, e a vontade não se representa: ou é ela mesma, ou é uma outra; não é meio termo. Os deputados do povo não são portanto nem podem ser seus representantes; são apenas os seus comissários: não podem concluir nada de modo definitivo. Toda lei que não tenha sido ratificada diretamente pelo povo é nada; não é uma lei. [...] A ideia dos representantes é moderna: ela nos chega vinda do governo feudal, desse iníquo e absurdo governo, no qual a espécie humana se degradou e o nome de homem se desonrou (Ibid. pp. 100-101).

Enfim o IV livro do Contrato é ignorado por Marx, exceção feita a uma passagem do capítulo 2 que retorna ao conceito de vontade geral. O problema põe-se nos confrontos da liberdade da minoria, que deveria ser ao mesmo tempo livre e sujeita às leis às quais consentiu. Eis a solução no extrato marxiano:

Quando se propõe uma lei na assembleia do povo, o que se pede aos 
cidadãos não é precisamente se eles aprovam a proposta ou se a rejeitam, mas se ela está conforme ou não à vontade geral, que é a deles: cada um dando o seu voto exprime a sua opinião; do cálculo dos votos se tira a declaração da vontade geral. Quando então prevalece a opinião contrária à minha, isso quer dizer apenas que eu me havia enganado, e que o que acreditava ser a vontade geral não era tal (Ibid., p. 144).

No conjunto, os excertos marxianos do Contrato social permitem corrigir um preconceito duradouro: que Rousseau teria constituído para Marx um modelo quanto a seu próprio conceito de democracia. Na verdade, trata-se do contrário. Se, de fato, retomamos brevemente os termos da problemática feuerbachiana através da qual Marx pensa a dialética de democracia e monarquia, em primeiro lugar, e de monarquia e república, em segundo lugar, fica claro que a democracia enquanto Gattungsverfassung é reapropriação daquela essência humana (enquanto humana, política) que se acha alienada tanto na monarquia quanto na república, porque projeção desta essência num objeto, o Estado, que se opõe como transcendente e estranho ao povo real. E não há qualquer traço da democracia entendida nesse sentido em Rousseau. Ao contrário, Marx encontra em Rousseau os termos-chave da alienação da essência humana no pacto social (a alienação total de cada associado), em benefício da criação de um ente metafísico que, depois, se opõe, como um algo estranho (a vontade geral) ao indivíduo e ao povo que o criou.

Se, portanto, o Contrato social foi para Marx um modelo, ele o foi não para pensar a democracia, da qual Rousseau faz uma desvalorização apenas em parte recopiada nos excertos marxianos, mas, antes, para pensar a república, negação da alienação monárquica no âmbito abstrato do Estado, que deixa todavia intactos os conteúdos da sociedade (propriedade, etc.) e a separação de público e privado. Além disso, se Marx pensa a democracia como verdade da monarquia, como Gattung, em Rousseau esse papel é confiado à república, da qual a monarquia é apenas uma espécie. 
É necessário, pois, buscar esse modelo de democracia em algum outro lugar.

6. Os excertos marxianos do Tratado teológico-político

Tentemos fazer a hipótese, seguindo a indicação negriana, de que Marx tenha encontrado esse modelo em Espinosa. Negri, ao referir-se a Espinosa, parece pensar no modelo democrático do Tratado político, no qual, nas poucas linhas que deixou, Espinosa definiu o imperium democraticum como omnino absolutum, absolutamente absoluto, do todo absoluto. Todavia, não existem vestígios de uma leitura naqueles anos do Tratado político, ao passo em que existem excertos marxianos do Tratado teológico-político, que, contudo, não pertencem ao mesmo período da redação da Kritik e dos cadernos sobre a história francesa: eles o antecedem em dois anos, redigidos na primeira metade de $1841 .{ }^{4}$ Fazem parte de uma série de cadernos que compreende também excertos da Correspondência de Espinosa, excertos de Humes, de Leibniz ${ }^{6}$, e um caderno exclusivamente bibliográfico da Geschichte der Kantschen Philosophie de Rosenkranz7 . Não me deterei aqui em uma leitura exaustiva dos excertos marxianos de Espinosa, dos quais propus uma leitura em outro lugar ${ }^{8}$, para focar a atenção exclusivamente nos excertos do capítulo 16 do Tratado teológico-polí-

4 "Exzerpte aus Benedictus Spinoza: Opera ed. Paulus", MEGA 2, 4, v. 1 ("Exzerpten und Notizen bis 1842") pp. 233-276. Marx extrai as passagens de Espinosa na edição Paulus: Benedicti de Spinoza, Opera quce supersunt omnia, Iterum emenda curavit, præfationes, vitam auctoris, nec non notitias, quae ad historiam scriptorum pertinent addidit Henr. Eberh. Gottlob Paulus Ph. ac. Th. D. huius Prof. Ord. Ienensis. Volumen prius. Ienæ in bibliopolio Accademico 1802. Volumen posterius. Cum imagine auctoris. Ienæ in Bibliopolio Accademico. 1803.

5 "Exzerpte aus David Hume: über die menschliche Natur" (MEGA 2, 4, v. 1, pp. 213232).

6 “Exzerpte aus Leibniz' Werke”, Ibid., pp. 183-212.

7 "Exzerpte aus Karl Rosenkranz: Geschichte der Kantschen Philosophie", Ibid., pp. 277-288.

8 V. Morfino, "Marx e Spinoza". In: M. Cingoli, V. Morfino (ed.). Aspetti del pensiero di Marx e delle interpretazioni successive. Milano: Unicopli, 2011, pp. 83-110. 
tico, no qual são fixadas as coordenadas fundamentais de sua teoria política.

Marx transcreve, em primeiro lugar, a definição espinosana de direito natural:

Por direito e instituto natural, não entendo outra coisa que as regras da natureza de cada indivíduo, segundo as quais concebemos que cada um é determinado a existir e operar de um certo modo. Assim, por exemplo, os peixes são determinados pela natureza a nadar e os grandes a comer os menores, donde dizemos que, por pleno direito natural, os peixes são senhores da água e os grandes comem os menores. [...] E, porque é uma lei suprema da natureza que cada coisa se esforce a persistir enquanto pode em seu próprio estado, e isso não em razão de outra coisa, mas apenas em razão de si mesma, segue daí que cada indivíduo tem pleno direito a isso, isto é, a existir e operar como é naturalmente determinado [...] Por isso, o direito natural é determinado não pela sã razão, mas pelo desejo e pela força (Marx, 1842, p. 240).

O essencial do jus sive potentia espinosano é reproduzido por Marx: o direito natural não é um dever ser, um sollen, mas coincide com a necessidade mesma da natureza, um mussen: o direito é a relação que se institui a partir do fato de determinadas relações de força. $\mathrm{O}$ peixe grande tem direito de comer o peixe pequeno porque tais são as relações de força.

Dirijamo-nos aos excertos marxianos sobre o nascimento da sociedade:

Veremos claramente que os [homens], para viver em segurança e do melhor modo, deveriam necessariamente unir-se e fazer de modo a ter coletivamente o direito que cada um por natureza tinha sobre todas as coisas, e que esse fosse determinado, não mais pela força e pelo instinto de cada um, mas pelo poder e pela vontade de todos. (Ibid.).

Todavia, esse convir dos homens através de um pacto não 
ocorre de uma vez por todas, mas pode a qualquer momento falhar, como precisa o excerto marxiano sucessivo: "Disso concluímos que o pacto não pode ter qualquer força se não em razão da utilidade, e que, subtraída esta, o pacto mesmo é simultaneamente anulado e permanece destruído". Como é possível então que se constitua uma sociedade "sem nenhuma repugnância do direito natural”? (Espinosa, 1925, p. 193). Eis a resposta de Espinosa no excerto marxiano:

Sob condições (...) de que cada um transfira toda sua própria potência à sociedade, a qual deterá assim sozinha o sumo direito natural sobre tudo, vale dizer, o supremo poder, ao qual cada um, livremente ou por temor de castigos, deverá obedecer. Esse direito da sociedade se chama 'democracia', a qual se define, por isso, como a união de todos os homens que têm coletivamente pleno direito a tudo aquilo que está em seu poder (Marx, 1842, p. 240).

Como consequência natural da lógica do jus sive potentia, o poder supremo manterá seu direito até quando mantiver sua potência:

Esse direito de impor tudo aquilo que querem [pois o poder da suma autoridade não é sujeito a nenhuma lei] subsiste apenas até quando detêm efetivamente o sumo poder: porque, se perdem este, perdem junto também o direito ilimitado de império, que cai nas mãos daquele ou daqueles que o conquistaram e que estão em condições de mantê-lo (Ibid., pp. 240-241).

Marx não transcreve a passagem seguinte na qual Espinosa afirma que é raro um ordenamento democrático dar ordens totalmente absurdas, dado, por um lado, que “é quase impossível que a maior parte de um consórcio, se ele é grande, convenha em um único absurdo", e porque, por outro lado, isso está excluído do princípio e da finalidade do ordenamento democrático, "que 
(...) é o de evitar os absurdos do instinto e o de conter os homens, na medida do possível, dentro dos limites da razão, a fim de que vivam na concórdia e na paz.” (Espinosa, 1925, p. 194) Portanto, conclui Espinosa num outro excerto marxiano,

em um regime político no qual é lei suprema a saúde não do soberano, mas de todo o povo, aquele que obedece em tudo à autoridade não deve ser definido escravo inútil a si mesmo, mas súdito; e livre em sumo grau é aquela república que tem suas leis fundadas na reta razão, já que, nessa, cada um pode, se quiser, ser livre, ou seja, viver integralmente segundo o ditame da razão (Marx, 1842, p. 241).

Enfim Marx transcreve uma linha fundamental do Tratado Teológico Político: “[...] governo democrático (...) me parece o mais natural e o mais conforme à liberdade que a natureza consente a cada um" (Ibid.).

Malgrado tenha sido afirmada por muitos intérpretes uma forte presença espinosana no Contrato social', não é difícil tomar os elementos que permitiram a Marx identificar em Espinosa, e não em Rousseau, o modelo de uma teoria da democracia como Gattungsverfassung. Enquanto em Rousseau, de fato, o indivíduo é definido antes do contrato com aquela verdadeira hendíade metafísica que é a expressão ‘pessoa e bem’ - e portanto o indivíduo é uma pessoa, uma entidade abstrata, livre, moral, sujeito de direito da tradição jurídica burguesa, e o contrato é uma instituição jurídica estipulada pela livre vontade, e portanto o Estado é um posterius em relação aos indivíduos mônadas, uma construção artificial, um ente metafísico universal -, em Espinosa os indivíduos que entram no pacto estão inteiramente imersos na imanência da

9 Cf. em particular M. Francès, "Les rèminiscences spinozistes dans le Contrat social de Rousseau", Révue philosophique de la France et de l'Etranger, 76, 1951, pp. 61-84. Cf. também P. Vernière, Spinoza et la pensée française avant la révolution. Paris: Presses Universitaires de France, 1954, P. $4^{81}$ e sgg. 
natureza, tanto que o direito de cada um deles é definido em termos de potência e o pacto não dá origem a um ente artificial nem no plano social - porque o convir dos indivíduos em sociedade (societas) é sujeito, a cada instante, à utilidade dos próprios indivíduos -, nem no plano político - porque cada forma de poder constituído no interior da sociedade mesma dura até onde dura sua potência.

Lendo o argumento marxiano que dá lugar àquela que chamamos dialética manca de monarquia e de democracia, sublinhamos a ascendência feuerbachiana do argumento. Agora é possível iluminar a forte ascendência espinosana, se pensamos no fato de que Espinosa chama de democracia o convir mesmo dos homens em sociedade e que, por isso, poder democrático é definido como o mais natural: torna-se então claro por que, segundo Marx, a democracia é a verdade da monarquia, pode ser concebida por si mesma, é Gattungsverfassung, "o enigma resolvido de todas as constituições", forma (summa potestas) e conteúdo (societas), essência (societas) e existência (summa potestas).

\section{Conclusões}

O modelo de pensamento político que Marx opõe a Hegel a respeito do parágrafo sobre a soberania revela ser, de fato, a teoria política espinosana, embora não nos termos exatos sugeridos por Negri. Não é, pois, a soberania enquanto ente metafísico abstrato que se encarna no corpo empírico do monarca (do qual será deduzida, provocando a feroz ironia de Marx, até mesmo a hereditariedade), mas a societas, o corpo social, que dá lugar à abstração da summa potestas: o mundo é recolocado sobre seus pés, a alienação é superada e, ao sujeito, é restituída a essência plena que se lhe era oposta como um objeto estranho que o dominava, o Estado. 
Contudo, não é preciso cair num erro ingênuo ${ }^{10}$ ao propor essa genealogia. Como escreve Marilena Chaui, deve-se resistir à tentação de fazer uma simples comparação entre Marx e Espinosa, dado que uma "comparação, como diz Espinosa, é um conhecimento inadequado, imaginativo e abstrato, que apanha semelhanças e diferenças imediatas, sem alcançar a essência da coisa" (Chaui, 1983, p. 268). Discutirei o erro nos seguintes termos: talvez a inserção forçada da teoria política espinosana dentro de um quadro de problemática feuerbachiana não conduza ao desconhecimento dos termos mesmos da teoria espinosana? Noutras palavras: é possível pensar a teoria política espinosana através do modelo de inversão sujeito-predicado, do povo (ou multidão, nesse nível não faz nenhuma diferença) entendido como sujeito pleno e transparente que vê sua essência genérica (Gattungswesen) alienada em um objeto estranho que se apresenta contrário a ele e do qual é suficiente reapropriar-se para se o ver dissolver-se no nada (o Estado que desaparece)? Não se perde assim a teoria espinosana da constituição do poder através da imaginação e dos afetos, da religião e dos ritos, da superstição e do conflito? Mas se perde também a especificidade da teoria espinosana do imperium que não é exatamente o Estado entendido como poder estranho que se opõe à sociedade, abstração e alienação da sua essência, mas antes como "conjunto articulado de instituições", "como a totalidade das instituições de uma sociedade, ou seja, que exprimem o direito natural de uma sociedade como essentia particulares" (Rocha, 2011, pp. 86-92), ou seja, se bem entendo a leitura de Rocha, como gramsciano Estado integral, isto é, Estado incindível da sociedade

10 Perfeito paradigma dessa ingenuidade parece-me a interpretação de Miguel Abensour, La démocratie contre l'État. Marx et le moment machiavélién. Paris: PUF, 1997. Abensour interpreta a democracia da Kritik como uma criação continuada do povo (criação que não gera o Estado, mas è precisamente contra o Estado), e vê a origem desse conceito em Maquiavel e Espinosa, sem todavia que os dois autores compareçam no texto senão como vagos fantasmas, privados até mesmo da mínima consistência conceitual. 
já que existe só através das relações de força e nunca como essência pura, transparente, não contaminada. Não será nisso que Espinosa se demonstra o único verdadeiro herdeiro de Maquiavel?

Sem dúvida, Negri diz que a teoria da democracia absoluta e da alienação é idealista com respeito aos tempos de Marx, mas que, ao contrário, torna-se perfeitamente verdadeira com respeito aos nossos tempos, tempos que são - para dizê-lo brevemente tempos do general intellect prefigurados por Marx no Fragmento sobre as máquinas dos Grundrisse. Esta afirmação, ao invés de iluminar Espinosa e Marx, parece-me iluminar o próprio Negri e um forte elemento feuerbachiano presente em seu pensamento, presente não apenas na sua definição do poder constituinte como um "deus vivo democrático", mas também na inversão sujeito-predicado que ele propõe a respeito do general intellect, de poder estranho, que se opõe ao homem, a essência genérica humana. Nessa passagem, a meu ver, falta a política como invenção e organização, como intervenção estratégica, falta a virtude em sentido maquiaveliano.

Referências bibliográficas

ALTHUSSER, L. Pour Marx. Paris: Maspero, 1965. "Sur Feuerbach." In: MATHERON, F. (ed.). Écrits philsophiques et politiques. Paris: Stock/IMEC, 1995.

CHAUI, M. "Marx e a democrazia (o jovem Marx leitor de Spinoza)”. In: FIGUEIREDO, E. L. (ed.). Por que Marx?. Rio de Janeiro: Edições Graal, 1983, pp. 257-292.

ESPINOSA, B. Tractatus theologico-politicus. In: GEBHARDT, C. (ed.). Opera. . Heidelberg: Winters, 1925.

DELLA VOLPE, G. "Gli scritti filosofici postumi del 1843 e 1844 (La critica materialistica dell'a priori)". In: Rousseau e Marx e altri saggi di critica materialistica. Roma: Editori Riuniti, 1997. FEUERBACH, L. Vorläufige Thesen zur Reformation der Philosophie. In: SCHUFFENHAUER, W. (ed.). Gesammelte Werke.. Berlin: Akademie Verlag, 1970. 
HEGEL, G.W.F. Grundlinien der philosophie des Rechts. In: GROTSCH, K. e WEISSER-LOHMANN, E. (ed.). Gesammelte Werke, v. 14. . Hamburg: Felix Meiner, 2009.

MARX. K. "Aus Jean Jacques Rousseau: Du contrat social". In: MEGA, 4, v. 2. Berlin: Dietz Verlag, 1981. Critica della filosofia hegeliana del diritto pubblico. Trad. Galvano della Volpe. con aggiunte di Clio Pizzingrilli. Macerata: Quodlibet, 2008. "Exzerpte aus Benedictus Spinoza: Opera ed. Paulus". In: MEGA 2, 4, v. 1 (Exzerpten und Notizen bis 1842). Berlin: Dietz Verlag, 1842. . Zur Kritik der Hegelschen Rechtsphilosophie. In: MEGA, 1, v. 2. Berlin: Dietz Verlag, 1982.

ROCHA, A. M. Espinosa e a inteligibilidade da história. Ensaios sobre a liberdade e a democracia no Tratado Teológico-Político. Tese apresentada ao Departamento de Filosofia da Faculdade de Filosofia, Letras e Ciências Humanas da Universidade de São Paulo, 2011.

ROUSSEAU, J.-J. Du contrat social. In: Écrits politiques. Verona: Cofide, 2001. 
